\title{
COVID 19 comprehensive management in a regional hospital of Northwestern Spain
}

\author{
Cristina Sardiña-González, Manuel Lorenzo López-Reboiro, Rebeca Suárez-Fuentetaja, \\ Beatriz Ares Castro-Conde, Enrique Álvarez-Asensio and José López-Castro* \\ Hospital Público de Monforte, Department of Internal Medicine, Lugo, Spain
}

\begin{abstract}
Introduction: The COVID-19 pandemic has brought about a paradigm shift in healthcare. Objective: To evaluate the utility of a strategy to comprehensively address the pandemic in a health area that covers 42,000 people. Method: Between March 10 and May 15, 2020, the COVID Unit was created in the corresponding regional hospital, and an independent circuit was established for the diagnosis and management of patients with suspected or confirmed COVID-19; social health centers were monitored with PCR testing. Results: Eighteen COVID-19-positive patients (age $72.9 \pm 13.2$ years) were admitted, out of which $66 \%$ were males. All these patients had pneumonia and $67 \%$ had respiratory distress syndrome; no one required mechanical ventilation. Mean hospital stay was $9.4 \pm 5.3$ days, and mortality, $11 \%$. PCR tests were applied to all hospital residents $(n=827)$ and workers $(n=519), 1,044$ phone calls were made and 36 hospital admissions were avoided. Only 50 patients required close follow-up, out of which four (0.48\%) were positive for COVID-19. Conclusion: Clinical monitoring at the hospital and social health centers showed that patient profile was like that documented in the literature and that the incidence of COVID-19 was low in social health centers.
\end{abstract}

KEY WORDS: COVID-19. Public health. Comprehensive health strategies.

\section{Gestión integral de COVID 19 en un hospital regional en el noroeste de España}

\section{Resumen}

Introducción: La pandemia de COVID-19 provocó un cambio de paradigma en la atención médica. Objetivo: Evaluar una estrategia para abordar integralmente la pandemia en un distrito de salud que comprende 42000 personas. Método: Entre el 10 de marzo y 15 de mayo de 2020 se creó la Unidad COVID en un hospital regional correspondiente al distrito y se estableció un circuito independiente para el diagnóstico y manejo de pacientes con sospecha o confirmación de COVID-19; Ios centros de salud social fueron monitoreados mediante PCR. Resultados: Ingresaron 18 pacientes positivos a COVID-19 (edad de $72.9 \pm 13.2$ años), 66 \% eran hombres; todos presentaron neumonía, $67 \%$ desarrolló síndrome de dificultad respiratoria y ninguno requirió ventilación mecánica. La estancia hospitalaria fue de $9.4 \pm 5.3$ días y la mortalidad, de $11 \%$. Se realizaron pruebas de PCR a todos los residentes $(n=827)$ y trabajadores $(n=519)$ del hospital, se realizaron 1044 llamadas telefónicas y se evitaron 36 hospitalizaciones. Solo 50 pacientes necesitaron seguimiento cercano, cuatro (0.48 \%) positivos a COVID-19. Conclusión: El monitoreo clínico en el hospital y centros de salud social mostró que el perfil de los pacientes fue similar al documentado en la literatura y que la incidencia de COVID-19 fue baja en los centros sociales de salud.

PALABRAS CLAVE: COVID-19. Salud pública. Estrategias integrales de salud. 


\section{Introduction}

The COVID-19 pandemic represents a challenge for all health systems. ${ }^{1}$ In a very short period, it has forced decision-making to manage the care of patients with this disease, as well as the demarcation of differentiated circuits to avoid contact between uninfected, suspected or confirmed COVID-19-infected patients, for which new isolation rooms have been created in hospitals, and intensive care and intermediate care wards have been expanded.

Physicians have had to deal with the uncertainty of not knowing the evolution or specific treatments of the disease, and with unknown situations against the clock. $^{2}$ Institutionalized elderly people (residents of geriatric centers, which include sheltered housing and housing for people with disabilities) are the most vulnerable group, both to contagion and to COVID-19 infection-associated mortality, not only because of their age but also because they have more comorbidities and less intrinsic capacity, both cognitive and functional.

According to the research we carried out, the study herein presented is the first one to combine COVID-19 clinical monitoring in a regional hospital and in social health centers of the same health district.

\section{Method}

A prospective, observational study was conducted at Monforte Public Hospital, in Lugo, Spain, a regional hospital with 141 beds that serves a health district of 42,000 people and whose reference hospital is the Lucus Augusti University Hospital, in the same city. The COVID Unit is made up of internal medicine doctors and one geriatrician, who worked in a network with primary care services, social health centers and home hospitalization. A coordination plan was developed with the 11 social health or geriatric residences in the district, by means of which daily active telephone follow-up is carried out through a case-administering nurse, in order to identify patients requiring intervention. Patients are classified into two groups:

- Patients without infectious respiratory pathology, in order to reduce hospital admissions and visits to the emergency department, trying to promote medical care in the residential setting (in residences that do not have a doctor or nursing staff working with the home hospitalization team and primary care collaboration).
- Patients with respiratory infectious symptoms, who according to their phenotype were identified as robust and fragile.

Descriptive statistics were used to know the profile of the patient with COVID-19 and the reduction of hospital admissions by applying this working system.

\section{Ethical aspects}

All patients signed the informed consent form and their management was carried out in accordance with the documents recently published by the Ministry of Health, Consumption and Social Welfare of Spain.

\section{Results}

Only patients with COVID-19 and some risk factor or complication were candidates for hospital admission (asymptomatic patients were followed-up at their place of residence). Twenty-one patients were admitted, out of whom three were excluded: two who were transferred to the reference center and another one whose COVID-19 diagnosis had been established 15 days earlier and was asymptomatic all the time; hospital admission was due to abdominal aortic aneurysm.

The remaining 18 patients had an average age of $72.9 \pm 13.2$ years, most were males (66\%) and only $11 \%$ belonged to the health sector. As for comorbidity, $50 \%$ had hypertension, $17 \%$ had bronchopathy, and $17 \%$, obesity. On age-adjusted Charlson comorbidity index, $88 \%$ of subjects had a score of three points or more.

Respiratory symptoms such as dyspnea (78 \%) and cough $(61 \%)$ predominated, followed by flu-like symptoms such as asthenia (56\%), arthromyalgia (33\%) and anorexia (28\%). Ageusia and anosmia, symptoms that are highly suggestive of COVID-19, were only observed in $11 \%$ and $17 \%$, respectively. Gastro-abdominal symptoms were present in a minority; $17 \%$ indicated diarrhea, and $5 \%$, nausea. All patients had pneumonia, and $67 \%$, respiratory distress syndrome; no one required non-invasive mechanical ventilation. The treatments that were used were azithromycin and hydroxychloroquine $(87 \%)$, ritonavir and lopinavir (78\%), interferon (33\%), methylprednisolone boluses (61\%), tocilizumab (33\%) and low molecular weight heparins at intermediate or anticoagulant doses (72\%). The most common complications during hospitalization were acute confusional syndrome (22\%) 


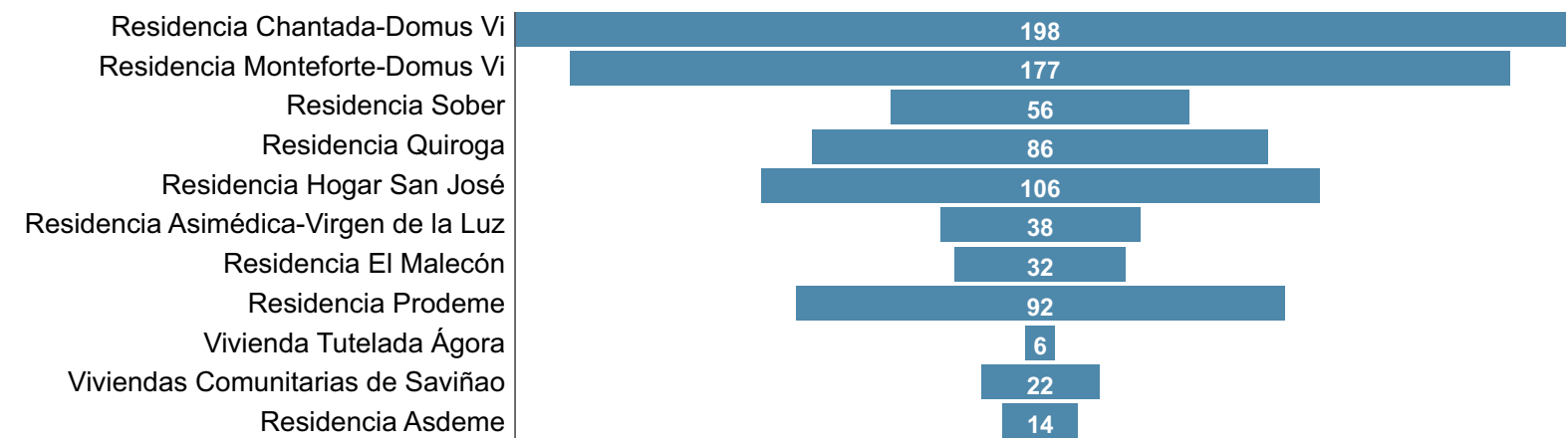

Figure 1. Number of residents by geriatric center.

Table 1. Clinical-therapeutic data, complications and evolution of 18 patients with COVID-19 cared for at Monforte Public Hospital, Spain

\begin{tabular}{|c|c|c|}
\hline Age in years (mean $\pm \mathrm{SD}$ ) & 72. & 3. 2 \\
\hline Hospital stay days (mean \pm SD) & 9.4 & \\
\hline & $n$ & $\%$ \\
\hline Male gender & 12 & 67 \\
\hline Health personnel & 2 & 11 \\
\hline $\begin{array}{l}\text { Comorbidity } \\
\text { Hypertension } \\
\text { Bronchopathy } \\
\text { Obesity } \\
\text { Charlson index } \geq 3\end{array}$ & $\begin{array}{c}9 \\
3 \\
3 \\
14\end{array}$ & $\begin{array}{l}50 \\
17 \\
17 \\
78\end{array}$ \\
\hline $\begin{array}{l}\text { Clinical manifestations } \\
\text { Dyspnea } \\
\text { Cough } \\
\text { Asthenia } \\
\text { Arthromyalgia } \\
\text { Anorexia } \\
\text { Ageusia } \\
\text { Anosmia } \\
\text { Diarrhea } \\
\text { Nausea } \\
\text { RDS }\end{array}$ & $\begin{array}{c}14 \\
11 \\
10 \\
6 \\
5 \\
2 \\
3 \\
3 \\
1 \\
12\end{array}$ & $\begin{array}{c}78 \\
61 \\
56 \\
33 \\
28 \\
11 \\
17 \\
17 \\
5 \\
67\end{array}$ \\
\hline $\begin{array}{l}\text { Treatment } \\
\text { Azithromycin } \\
\text { Hydroxychloroquine } \\
\text { Lopinavir-ritonavir } \\
\text { Interferon beta-1 } \\
\text { Bolus methylprednisolone } \\
\text { Tocilizumab } \\
\text { LMWH, intermediate or anticoagulant dose }\end{array}$ & $\begin{array}{c}15 \\
15 \\
14 \\
6 \\
11 \\
6 \\
13\end{array}$ & $\begin{array}{l}87 \\
87 \\
78 \\
33 \\
61 \\
33 \\
72\end{array}$ \\
\hline $\begin{array}{l}\text { Complications } \\
\text { Acute confusional syndrome } \\
\text { Diabetic decompensation } \\
\text { Bacterial respiratory superinfection } \\
\text { In-hospital mortality }\end{array}$ & $\begin{array}{l}4 \\
2 \\
1 \\
2\end{array}$ & $\begin{array}{c}22 \\
11 \\
5 \\
11\end{array}$ \\
\hline
\end{tabular}

and corticosteroid-induced diabetes (11\%). Bacterial respiratory superinfections accounted only for $6 \%$
(Table 1). Average hospital stay was $9.4 \pm 5.3$ days, and hospital mortality, $11 \%$.

As for the coordination plan with social health centers, out of 827 residents of the 11 geriatric centers in the district (Fig. 1), 50 were included, with four $(0.48 \%)$ being SARS-CoV-2-positive. The common symptom in all four cases was high fever; three also had non-productive cough, and only one, dyspnea; three were treated in the residence with hydroxychloroquine for five days and azithromycin for three days, in addition to empirically-prescribed antibiotics; the fourth one was a patient with high prior dependence, which is why he was transferred to the regional hospital, since adequate medical care could not be guaranteed in the geriatric center due to the lack of medical or nursing personnel. During the program follow-up, PCR tests were made to all residents and workers $(n=519)$, 1044 telephone calls were made and 36 hospital admissions were avoided, with an estimated saving in direct costs of $111,396.87$ euros.

\section{Discussion}

The studied patients were elderly, mostly males and with comorbidities, as it has been described in previous studies. ${ }^{3-5}$ No one experienced clinical thromboembolic disease, an event that is being reported with high recurrence in the literature. ${ }^{6}$ In the absence of an effective treatment against COVID-19 so far, the cornerstone of management is transmission prevention, which at the community level is carried out by early confinement and by trying to keep infected individuals at home during their illness, whenever possible. This measure is likely to be the fundamental key to the low transmission rate in the health district covered by the Monforte Public Hospital, together with the implementation of absolutely separate COVID and non-COVID circuits and implementation of a dynamic home care 
network, which in other recent studies has been shown to be relevant. ${ }^{7}$

Medical treatment was based on hydroxychloroquine and azithromycin, as indicated in initial studies. ${ }^{6}$ Low molecular weight heparin was also applied at intermediate doses for prophylaxis; in selected cases, even at anticoagulant doses, taking into account that SARS-CoV-2 is extremely prothrombogenic. ${ }^{8}$

Nine- or 10-day hospital stay was shorter than that described in the literature, since deaths occurred within the first 15 days and cases that evolved adequately were discharged in less than two weeks.

Being a small series, mortality does not allow a rigorous interpretation; however, it was slightly higher than global rates. ${ }^{9,10}$ Despite the limitations of this study, such as the small sample size, which makes inferences impossible, in these moments of uncertainty, disseminating truthful data that progressively increase knowledge about COVID-19 is necessary.

\section{Conclusions}

Our results indicated a low incidence of COVID-19 cases registered in social health centers, perhaps due to early confinement, population dispersion, combined management between the hospital and social health care, as well as the transfer of patients only for essential reasons.

The profile of the COVID-19 patient who was admitted to Monforte Public Hospital was similar to that documented in the literature; the higher rate of mortality was mainly due to significant comorbidity and advanced age. The low incidence of COVID-19 cases recorded in social health centers of the Monforte de Lemos Health District stands out. The main reasons for this include multidisciplinary work and patient-centered care, which is carried out cross-sectionally between hospital and residential settings, in addition to comprehensive performance of PCR testing in geriatric centers' residents and workers. Other factors that influenced on the low incidence of cases are geographical dispersion of the district population and the state of sanitary emergency and confinement decree before cases were documented in the region.

\section{Conflict of interests}

The authors declare that they have no conflicts of interest.

\section{Funding}

The authors did not receive any sponsoring to carry out this article.

\section{Ethical disclosure}

Protection of people and animals The authors declare that no experiments were performed on humans or animals for this research.

Confidentiality of data The authors declare that they have followed the protocols of their work center on the publication of patient data.

Right to privacy and informed consent The authors have obtained informed consent from the patients and/or subjects referred to in the article. This document is in the possession of the corresponding author.

\section{References}

1. Paules $\mathrm{Cl}$, Marston HD, Fauci AS. Coronavirus infections-more than just the common cold. JAMA. 2020;323:707-708. DOI:10.1001/ jama.2020.0757

2. López-Reboiro M, Sardiña-González C, López-Castro J. COVID-19 y Argumentum ad ignorantiam o "no todo vale". Rev Clin Esp. Rev Clin Esp. 2020 May 4. DOI: 10.1016/j.rce.2020.04.01

3. Chen N, Zhou M, Dong X, Qu J, Gong F, Han Y, et al. Epidemiological and clinical characteristics of 99 cases of 2019 novel coronavirus pneumonia in Wuhan, China: a descriptive study. Lancet. 2020;395:507-513.

4. Guan W, Ni Z, Hu Y, Liang W, Ou C, He J, et al. Clinical characteristics of coronavirus disease 2019 in China. N Engl J Med. 2020;382:17081720 .

5. Wang B, Li R, Lu Z, Huang Y. Does comorbidity increase the risk of patients with COVID-19: Evidence from meta-analysis. Aging (Albany NY). 2020;12:6049ロ6057.

6. Zhou F, Yu T, Du R, Fan G, Liu Y, Liu Z et al. Clinical course and risk factors for mortality of adult inpatients with COVID-19 in Wuhan, China: A retrospective cohort study. Lancet. 2020;395:1054-1062.

7. Sánchez-Duque JA, Arce-Villalobos LR, Rodríguez-Morales AJ. Coronavirus disease 2019 (COVID-19) in Latin America: Role of primary care in preparedness and response. Aten Primaria. 2020;52:369-372.

8. López Castro J. COVID-19 and thrombosis: Beyond a casual association. Med Clin (Barc). 2020.

9. Wang X, Fang X, Cai Z, Wu, X., Gao, X., Min, J. et al. Comorbid chronic diseases and acute organ injuries are strongly correlated with disease severity and mortality among COVID-19 patients: A systemic review and meta-analysis. Research (Wash D C). 2020;2020:2402961.

10. Jan H, Faisal S, Khan A, Khan S, Usman H, Liaqat R, et al. COVID-19: Review of epidemiology and potential treatments against 2019 novel coronavirus. Discoveries (Craiova). 2020;8:e108. 